\title{
A New Role for Global Cities. The Genoa Case
}

\author{
Raffaele Gazzari*
}

\begin{abstract}
Over recent years, strategic planning constituted for many Cities an effective answer to the problem of competitive territories' development.

In competitive land dynamics, through the adoption of strategic planning processes, the control of two fundamental and tightly linked aspects becomes possible:

- creating and strengthening the structural conditions that favors the local socio-economic system;

- being able to influence the complex dynamics behind reorganization opportunities to create wealth and by attracting resources and competences to the area.
\end{abstract}

Keywords: Global Cities; Strategic Plans; Globalisation; Governance; Social Development

\section{Cities and the Challenge of Globalisation}

Market globalisation is bringing about a considerable change in a logical and methodological aspect of the public sector intervention. The framework that is beginning to appear is giving ever greater importance to competition between geographical areas. This is aimed at creating and strengthening the socio-economic conditions, resources and competences required in order to generate competitive advantage and support local development and social progress ${ }^{1}$.

The systemic economic change rhythm imposed by the globalisation is, however, often much faster than the pace of political, civil and institutional society. Administrative, social and educational systems have not been able to keep up with the evolving process and the gap has had significant effects on inequality, exclusion, disunity and social break-up ${ }^{2}$. Unlike the corporate sector, the public sector has had great difficulty in facing the challenges of globalisation. In some cases it has ended up by submitting to globalisation's dominating influence with respect to key political country-system development decisions.

* Genoa City Hall, Chief of Cabinet (relint@comune.genova.it)

Gazzari Raffaele, A New Role for Global Cities. The Genoa Case, Symphonya. Emerging Issues in Management (symphonya.unimib.it), n. 1, 2004, pp. 27-42 
The governmental gap at national, regional and local levels is evident if we consider that the companies are amongst the few organisations able to cross all globalisation thresholds at the same time. In particular:

- size thresholds: are international and go beyond nation-state borders;

- time horizon thresholds: follow long term strategies that cannot be compared with traditional political and administrative system mechanisms controlling national and local governments;

- complexity thresholds: can effectively manage differences, coexistent multiple approaches, risk, resource development and quickly adapt to the uninterrupted environmental changes;

- information and communication thresholds: in other words, they are globally connected and act effectively and immediately ${ }^{3}$.

The benefits achieved by having overtaken these barriers have often led companies to challenge governments on the setting of local development guidelines ${ }^{4}$. However, considering numerous difficulties faced by the public administration it can be easily noticed that the globalization challenges impose a shift from its social dynamics restraining role to the new one- a catalyst for socioeconomic development in the areas and communities administered.

Hence, in this context $t^{5}$ :

- maintaining and strengthening an area's development conditions means strategic and operational action thought out, developed and implemented at local level

- local political system ability and flexibility become critical when meeting and winning against challenges in the environment.

Given these objectives, the logic behind action and generally how local administration and public administration intervene must change. The complexity and interdependence of socio-economic problems lead the public sector away from the action logic of the end of the 70s. Then it was felt that public intervention could solve all the problems - based on the assumption that the direct state production of public goods was the best way to ensure the satisfaction of citizens collective needs.

At local level, this means that defining and assessing community development strategies is not just the town administration's responsibility but requires the participation of all area operators, both public and private.

The township has to take on the main role in formulating strategy and development policies at local level. It refers non only to its approval role but also to an active involvement by both, public and private players interested in the development, consolidation and maintenance of competitive conditions in a specific area. It finds itself in the centre of a complex system where its role is one of development process coordinator - managing town development ideas, programs and resources.

A local authority's governance decisions suffer immensely from relations with citizens, companies and other local community players. Achieving authority's objectives and targets is often influenced by a coordinated action of various players and by the authority's ability to govern the relationship system successfully ${ }^{6}$. Hence, at local level it is not the township answering the globalisation challenge but the city as a whole, an expression of public and private operators interacting 
within a specific historical, natural, social and economic environment. It has to achieve excellent outcomes by giving added value to resources, competences and energy present within its domain.

\section{Strategic Planning as an Answer}

Over recent years, many cities have found strategic planning to be an effective and prompt answer to problems related to the territorial competitiveness development. In fact, in the light of the strategic planning processes, two fundamental and mutually related aspects become evident:

- creating and strengthening structural conditions that favour the local socioeconomic system over other geographical areas (not necessarily adjacent)

- being able to influence the complex dynamics behind reorganisation opportunities to create wealth through research and by attracting better development resources and competences to the area.

Strategic planning is not simply aimed at specific economic performance indices such as GDP, increased investment and consumption. Hence we cannot just refer to growth in economic wealth but must reflect on medium-long term choices able to allow development while adding value to available resources and existing competences, together with the ability to regenerate them.

The strategic analysis of area's resources, competences, critical aspects and development opportunities must consider three fundamental elements ${ }^{7}$ :

- territorial economic competitiveness: assessment of different economic factors aimed at defining and adding value to local specialization: industries operating in the area, existing professions, infrastructure supporting the manufacturing system, technology level, market conditions, etc.

- environmental sustainability of the development model adopted: refers to assessing quality of available environmental resources, environmental impact generated by economic activities, usability of urban space, etc.

- social cohesion and the relationship system: refers to the values inspiring and governing relationships between people, associations, companies and institutions operating in the area, together with inter-relations with other local, national and international systems. Hence all factors defining an area's historical, cultural and social identity must be considered.

'The city', with its complex combination of public institutions, social and civil forces and economic world with which they identify, is in the forefront of this strategic planning process. This process emerges as a voluntary, political action aimed at building a coalition around shared strategic directions it undertakes to plan and implement.

The success of the planning process also requires that it:

- is developed using informal logic and tools, not bound by laws; the factor aggregating the different coalition forces is an intent to create a significant change in the area's development conditions; 
- knows how to develop a vision covering all the area's strong and weak points; creating general strategies able to achieve widespread approval and remain stable over time ${ }^{8}$;

- is able, at the same time, to concentrate on a few clear, important objectives for concrete change. In fact, it allows to 'polarize' the energies, resources and local investments;

- is structured during both the planning and implementation stages so as to ensure clear links to strategic targets, the means used to achieve them and responsibility by people called to implement them.

Furthermore, the main strategic planning outcome, as analysis of the Genoa experience shows, is manifested by a stable, organised public and private player network representing the overall area in which they operate. Thus, even before the 'Strategic Plan' and its targets emerges, strategic planning is of key importance for the development of a new way of confronting and sharing problems and needs, plus resources, competences and experience. Long term, these become the real tangible and intangible assets creating the well-being and success conditions for a specific area.

\section{The Genoa Strategic Plan}

\subsection{The City's Socio-Economic Context}

During the last decade of the 20th century, the city of Genoa had to deal wit a socio-economic model crisis much as other western administrations had to. The most important critical factors included:

- crisis in large state shareholder corporations;

- difficulty in developing the harbour and associated infrastructure. Problems linked to relations between the harbour system and the rest of the city were of particular importance;

- demographic crisis linked to growth in the older population and new social needs;

- oblivion concerning the town's art and cultural heritage.

At the same time, added value and development opportunities were strong in:

- geographical, environmental and cultural terms resulting from proximity to the sea and a great artistic heritage yet to be re-discovered;

- social capital, network, political and area identity terms, mainly resulting from recent large industry development, e.g. the university, the training and professional system and the size of associations.

With regard to these critical aspects and opportunities, there was a need for a profound rethinking aimed at:

- delineating a new idea of the city, with strategic support that can bring together the main social, cultural and economic players;

- forming the basis for public institution actions, with the city administration at the forefront. 
Assessment of successes at the start of the 1990s referred particularly to the relations recovery between the city and sea achieved within the ancient port area for the 1992 Columbus celebrations. The reorganisation of port facilities and strong business recovery highlighted that profound transformation and significant improvements were possible as long as:

- changes were medium-long term (10-15 years) and took account of the complexity of what was needed from a technical, economic and institutional/administrative point of view;

- the vision was shared as widely as possible, was sufficiently well structured to be recognisable of itself and protected against the contingent difficulties arising from differing assessments that each institutional and socio-economic player involved would make (e.g., due to industry or political bias resulting from changes in the ruling majority).

\subsection{The Institutional Context}

At an institutional level, two basic aspects caused context conditions pushing Genoa and other Italian cities towards strategic planning processes:

- progressive state institutional and administrative decentralisation aimed at increasing local authority autonomy and responsibility for local government;

- growing attention over national and European public budget policy compatibility with resulting reduction of financial transfers towards local and area authorities.

It is necessary to say that mayoral elections played a preeminent role in the process by generating a close alignment between the responsibility for the community administered and relations with the environment that expressed area needs and had available resources. In order to really fulfil his/her role, a mayor, especially of a large city, has to develop governance behaviours and tools that go beyond administrative competence and the town's financial and organisational resources as such. This better involves those players who form the socio-economic fabric and actively relates to other local and national institutional levels.

The mayor's 'Mandate Program' must not simply consider services and outcomes from the specific city administration, but all town needs and development potential. It means launching programs and processes involving the different players in interinstitutional and public/private relationship terms which cannot count on stable, unitary, defined, formalised organisational and operational tools. These programs and processes count on the cooperation that area leadership manages to set up, doing its best to combine the attributes and resources of different institutions with needs and opportunities found in the area.

As city administration represents the area directly through the leadership of an elected mayor, it finds itself:

- having to be able to promote adequate strategic planning;

- while linking to its institutional and planning tools in terms of content, flexibility and development capacity - especially in reference to local governments. 
From this point of view, Genoa's strategic planning process developed in a context where, faced by a strong local governance need, there were significant gaps linked to specific individual institution attributes. In particular, the main aspects of the Genoa institutional context were:

- relations between city, province, region and central authorities in an area where the city of Genoa represents a great majority (in terms of population, production and GDP of the entire Region);

- relations between city and port (one of the biggest in the Mediterranean and by far the biggest entity in the region) very different to North European experiences';

- relations with central authority, historically important considering the a remarkable presence of the State as a shareholder in industry.

\section{Phases in the Strategic Plan}

\subsection{Towards the Strategic Conference (1998-1999)}

At the start of the city administration mandate at the end of the 1990s, it decided to face the above-mentioned problems. It launched an analysis, assessment and proposal period involving the city's main economic, social and cultural elements (Figure 1). This period, called 'Towards the Strategic Conference', started with a workshop on the city government methodology required, then continued through different workshops involving citizens, associations, manufacturing and scientific organisations with their specific interests and demands.

The main administration objective was to answer the question: 'how do we go about ensuring desirable, sustainable development for our city?', through:

- launching structured dialogue with all the town's public and private players;

- collecting feasible ideas and projects all sectors;

- establishing the sharing of the town's development process.

Figure 1: The Strategic Planning Process and Connection with Organisational Change Within the Administration

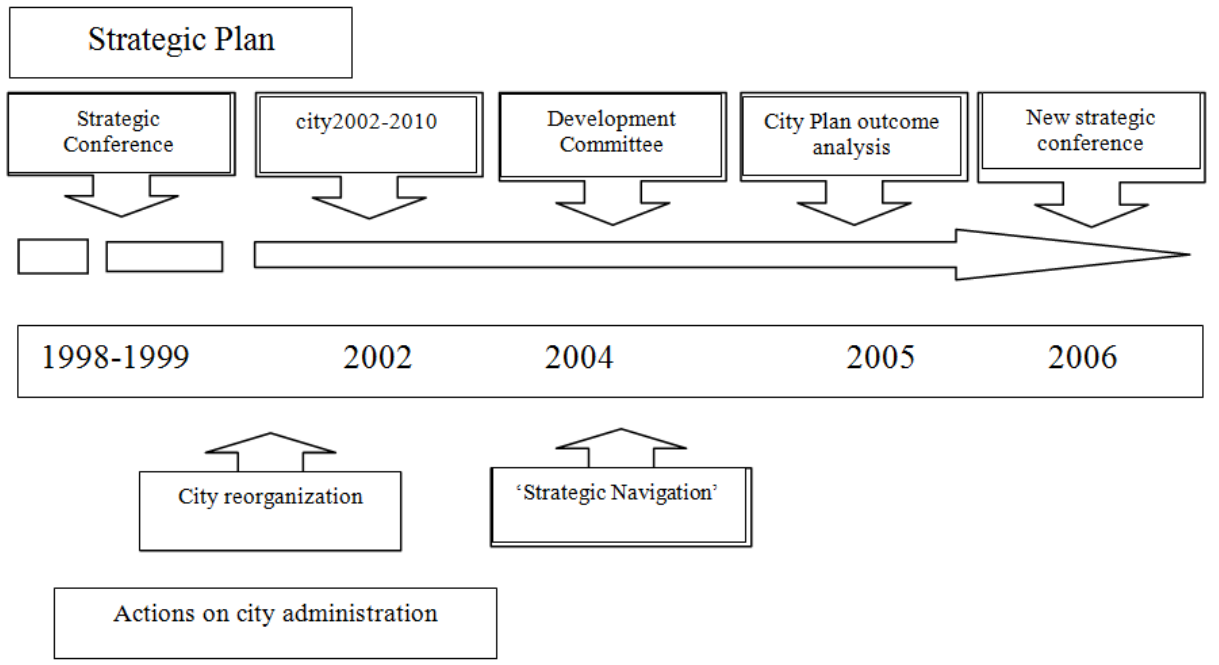


Preparation, setting up meetings and processing documents took 6 months and was coordinated directly by Councillors skilled in the different areas supported by Administration offices. The sharing process saw its first outcome in the Strategic Conference held on 12-13-14 May 1999. Participation at the Conference was impressive. More than 250 manufacturing, social and cultural associations from all over the area took part and there was an average of 500 people present at each of the six discussion sessions.

On the basis of the preparatory phase, the Conference opened by defining a new idea of city based on the following strategic points:

- A City's City: to acknowledge and add value to specific area aspects while opening out to major relations with surrounding small towns ${ }^{10}$;

- Polycentric development (port, industry, tourism, services): to overcome rigid alternatives that often bring about conflict and paralysing excuses and move towards recognising and achieving effective growth;

- Be part of North West Italy: to find essential area-based development synergy and restore what had been the so-called 'industry triangle' (Piedmont, Lombardy, Liguria) during the first half of last century - this time founded on 'division of labour' generally strongly directed towards central government (mainly state shareholder entities);

- Be a port to and from the Mediterranean: to again match geographic position, culture and history with the Marine Republic of Genoa - a significant economic force in past centuries.

During the Strategic Conference, the first document called 'The City Plan' was drawn up. This was the first step towards a real strategic plan ${ }^{11}$. On the whole, the Conference was a success as far as two important targets were achieved:

- sharing strategic town development through actively involving all society members;

- drafting a detailed plan/programme of strategic lines, targets and actions that also became a reference point for administrative activity.

A third objective, to create a Steering Committee through which the entire process would evolve and be monitored was more complex and ended with the creation of the Development Committee in 2004. This is discussed further on. This Development Committee was affected by the difficulty experienced in setting up governance bodies in the presence of authorities that each had specific city's attributes and, above all, elected or independently appointed bodies (region, province, city, Chamber of Commerce, Port Authority) all particularly sensitive to the political majority and position changes. Hence no formal governance body could be set up. However, consistent with said structure and with the city Plan, it was possible to effectively on important individual objectives and actions like preparing and managing 'Genoa, European capital of culture, 2004' through the agreement and coordinated government.

\subsection{City Council Reorganisation}

Contemporaneously to Strategic Conference, 1999 saw the start to redefining the City Council organisation as it was intended to become an 'open system'. 
Orientation towards the citizen/customer ${ }^{12}$ was the central reference point for the reorganisation: our customers are not just served by individual Council offices but by a complex network of suppliers from many public and private institutions or directly through self-organised participation. Thus, even in service supply (and not just for area development) the City Council can act as a network integrator (sensor, coordinator and promoter) instead of just producer or simply a direct financier.

The Council structure was transformed in three dimensions:

- decentralisation: through creating 9 area divisions bringing public action closer to service needs but also to response capacity;

- externalisation: through creating independent companies and institutions not just to achieve manufacturing/industrial service efficiency conditions but also to slowly set up management bodies and tools suitable for participation by other public and private bodies that can and must contribute to outcomes;

- reduction in central organisational structures: to free them from operating functions and re-assign resources to planning and design alongside other city operators.

From a structural point of view, we need to mention the setting up of a 'City Plan Project Unit' to support the City Executive Board in managing and updating the strategic plan, coordinating the main urban and infrastructure projects within the city area, dealing with appropriate council offices and other local and national public authorities as well as with any private parties involved. All this structural action was also associated with a fourth aspect: development of planning and control mechanisms. These mechanisms ensure coordination and integration for an organisation open to external, decentralised area environments through specific companies and institutions.

Besides creating and managing the 'City Plan', developing planning and control systems meant increased care over drafting and managing three-year planning tools such as the three-year budget and related Forecast and Programme Report, the Public Works Three-year Plan and implementation of a yearly budgeting and MBO (management by objectives) procedure (assigned to managers by the Executive Board), with three-monthly control both of financial aspects and of effectiveness and quality concerning the main activities.

\subsection{The Genoa City Plan (2002)}

With the City's representative elections over, and re-election of the sitting mayor, there was an opportunity to conduct the first outcome analysis of what had been planned at the 1999 Strategic Conference and what had effectively been carried out. A stable Administration made it possible to define future guidelines supported by projects, either on-going or planned, sufficiently concrete and feasible across all strategic areas for the City Council to act upon.

During a convention with the main institutional, economic, cultural and association representatives, the City Plan was structured and further organised into three books:

- Book One - 1999-2001 'Balance sheet', with the main city development considerations and a report on the main actions carried out, on-going or planned in strategic government areas; 
- Book Two - Framework of targets and individual actions, with 'cards' describing actions taken, on-going or planned;

- Book Three - 'Book of facts', figures and pictures, with a selection of pictures and statistics, historical visual record of a process still not over but something its citizens can be proud of.

As we said above, the 2002 Plan allowed strategic planning tools to be structured better and to be integrated with management and operational planning tools. In particular, the City Plan extended till 2010, with 7 strategies:

- everybody's city: targets actively promoting people during different life stages;

- quality city: targets aimed at urban renewal and re-balancing the area;

- economy and labour city: targets for compatible development and employment;

- Superb city: targets adding value to the town's historical heritage for communication and marketing purposes;

- port capital: targets to develop the port system and its infrastructure;

- cultural capital: targets to make sure the European Culture Capital 2004 event had a structural, long-lasting effect identifying Genoa as a City of Art:

- city management: targets adding value to participation and rationalising organisational structures, service supply and use of financial resources and assets available directly - based on different strategies.

In concrete terms, these 7 strategies were developed through 35 targets, in turn split into 136 actions (Figure 2). The card for each action acts as the basic information tool turning targets into concrete projects: with the descriptive and quantitative parts helping to recognise outcomes, single out roles and people involved, determine implementation times and forecast resources and related sources.

The City Plan action 'schedules' are an obligatory reference point for the planning documents. In particular, for RPP where contents (reason for program, targets and related sums available) must be declared by the managers responsible and Councillors as being consistent with them. In turn, yearly targets and budget assigned to managers by the City Executive Board must be consistent with the three-yearly plans. Naturally, this is not mechanical. Besides, it is not practical technically. Although all possible correlations have been made, even by adapting software, there are still classification type limits arising from the three-year national plans. It would be inadequate from a conceptual point of view.

Financial and budget planning documents basically refer to the related City Council resources. They do not consider a lot of private resources or resources from other administrations - a considerable proportion, if not the major source, for achieving targets and implementing City Plan actions ${ }^{13}$.

The most important consistency aspect across the three programming levels and the commitment to level integration (City Plan, multi-year Budget and City Council's yearly budget) regards the support the programming process gets and the call for responsibility and suitable behaviour that the main decision-making (Executive Board and Council) and managerial (managers) players make to ensure the development. 
Figure 2: 2002 City Plan: an Example of the Link Between Strategies, Targets and Actions.

\begin{tabular}{|c|c|}
\hline \multicolumn{2}{|c|}{$\begin{array}{c}\text { Actions for Strategy no. } 1 \\
\text { Everybody's City }\end{array}$} \\
\hline $\begin{array}{l}\text { Promoting } \\
\text { opportunities and } \\
\text { child and teenager } \\
\text { rights }\end{array}$ & $\begin{array}{l}\text { - Increase in the number of crèches and } \\
\text { new opportunities for the } 0-3 \text { age bracket } \\
\text { - Nursery schools for Genoa children } \\
\text { between } 3 \text { and } 6 \\
\text { - Child-friendly city: projects financed by } \\
\text { Law } 285 / 97 \text { (Turco Law) } \\
\text { - Child-friendly town: Area Education } \\
\text { Laboratories }\end{array}$ \\
\hline $\begin{array}{l}\text { Support for } \\
\text { education, for the } \\
\text { right to study and } \\
\text { for training } \\
\text { processes for } \\
\text { everyone }\end{array}$ & $\begin{array}{l}\text { - Promote the right to study, preventing } \\
\text { and combating school problems, improve } \\
\text { school premises } \\
\text { - Develop inter-cultural projects. The } \\
\text { 'School Centre and new cultures' } \\
\text { - International baccalaureate organisation } \\
\text { (I.B.O.) and new proposals for schools } \\
\text { - Quality certification for school meals }\end{array}$ \\
\hline $\begin{array}{l}\text { Improve university } \\
\text { education offering, } \\
\text { research and better } \\
\text { student lodgings }\end{array}$ & $\begin{array}{l}\text { Develop the university facilities at Balbi } \\
\text { and Darsena for synergy between } \\
\text { historical centre and old port } \\
\text { - New Engineering Faculty in old port } \\
\text { (Hennebique silo) } \\
\text { - Inauguration of the Political Sciences, } \\
\text { Education Sciences and Law Faculties at } \\
\text { the old Poor Shelter } \\
\text { - Creation of public lodgings for students } \\
\text { in the historical centre }\end{array}$ \\
\hline $\begin{array}{l}\text { Protection for the } \\
\text { elderly }\end{array}$ & $\begin{array}{ll}\text { - } & \text { Increased home support for the elderly } \\
\text { - } & \text { Rationalising and increasing residential } \\
& \text { facilities } \\
\text { - } & \text { Involve the elderly } \\
\text { - } & \text { Autonomy and protection for the disabled } \\
\text { - } & \text { Increased facilities for the disabled living } \\
\text { alone and services and intervention to } \\
\text { encourage personal autonomy }\end{array}$ \\
\hline $\begin{array}{l}\text { Policies for the } \\
\text { inclusion of the } \\
\text { marginalized and } \\
\text { race integration }\end{array}$ & $\begin{array}{ll}- & \text { Homeless inclusion policies } \\
- & \text { Itinerant inclusion policies } \\
- & \text { Policies to include people in difficulty } \\
- & \text { Initiatives to favour cultural integration }\end{array}$ \\
\hline $\begin{array}{l}\text { Protection of } \\
\text { childhood, young } \\
\text { people and families }\end{array}$ & $\begin{array}{ll}- & \text { Launch and consolidate action for } \\
\text { families together with residential } \\
\text { facilities for minors } \\
\text { - } \quad \text { Consolidation of empowerment processes } \\
\text { - } \quad \text { Minimum starting salary }\end{array}$ \\
\hline $\begin{array}{l}\text { Develop a } \\
\text { networked town }\end{array}$ & $\begin{array}{ll}\text { - } & \text { Participative and co-participative } \\
\text { planning as a work method for social and } \\
\text { education processes } \\
\text { - } \\
\text { Promote participation in European } \\
\text { processes }\end{array}$ \\
\hline
\end{tabular}




\section{4 'Strategic Navigation'}

The concerted nature itself of strategic planning in a large city like Genoa places process structure at the forefront. The grouping of different independent institutional players together with complex targets and actions (for different reasons: technical/norms, available financial resources, multiple interests, etc.) require continual adaptation at decision-making and management levels. Limits and opportunities cannot be defined just once. They must be handled and managed effectively, request flexibility, constant attention and suitable leadership qualities.

In order to respond to the need for continual updating, the decision was to change the way the Executive City Board works: the Board's weekly meetings are where strategic planning takes place. It is here that decisions are formalised (deliberation) but it is also where the Board acquires information and analyses and checks its basic targets. Hence, alongside the traditional, formal Minutes of Executive board meetings, informal minutes were introduced to support the Mayor and Councillors on the subjects dealt with. Each topic is described briefly in terms of content and actions, indicating the responsibilities of person involved as also the time it requires.

Starting in 2004, topics were split into three categories: informative, managerial (for measures involving managers and offices) and programming. The last topic is when the need to regulate and adapt strategic planning is done, both to solve difficulties that have arisen and for new opportunities ${ }^{14}$.

\subsection{Reactivating the Development Committee (2004)}

As mentioned above, it had not been possible to create governmental entities representing the main public zone institutions, private, manufacturing and social entities to manage all stages in relation to actions planned for the implementation of the first Strategic Conference decisions. Despite awareness of its importance and the willingness, though not as much as expected, of the main parties involved, it proved to be:

- too technical with the risk of it becoming too independent and distant from institutional roles and bodies;

- a substitute for institutional parties, especially public entities, formally having to make decisions.

Different alternating political majorities in local eligible institutions, with direct and indirect repercussions on other organisations, did not make things easier. It was only in 2004, following the positive 'Genoa, European capital of culture' experience that conditions were ripe to re-propose the creation of that meeting opportunity for the city's main public and private players ${ }^{15}$. Organisation of an initiative requiring significant renewal of artistic and urban heritage and of events (exhibitions) ensured historic recovery and the prospect that it would last. Besides being an immediate success, it strengthened the need for a medium term town development strategy as a whole.

Grabbing this opportunity, the mayor suggested to the town's main institutional and social players that it was the right moment to launch an individual planning entity called the 'Development Committee'. As stated above, the purpose was to 
give continuity to outcomes obtained through Genoa 2004, to promote the town and extend action to other strategic areas, especially for economic development.

The initial Committee was set up at the mayor's initiative together with the President of the Province and the President of the Liguria Region. Members were: the Presidents of the Port Authority and the Chamber of Commerce, the University Rector, President of the Industrialists' Association and officials from the three main area trade unions. After the first meetings, the Committee was joined by the main shopkeepers and craftsmen associations, plus the Solidarity and Labour Federation that groups the main social activist associations.

The Committee was set up as an informal body with the freedom to handle main city matters. It was to analyse and examine anything considered necessary, without in any way being ordained or even preordained by various institutional representatives making decisions. This approach led to a nimble organisation (technical secretary's office covered by the mayor's cabinet and by the Province President offices) that ensured systematic approach to the work. This formula has been positive and promising: the Committee meets every month. The main problems regarding the town's socio-economic structure have been handled and analysed (even by 'interviewing' company managers), both concerning crises (company restructuring) and development (port urban plan and variations; new technological centre).

Acquiring information and processing it all together has made it easier for individual area authorities to then make decisions and act. All elements lead to feeling that the Committee can carry out that active, area identity construction function to make the town's social capital recognisable and usable. The need to create specific subject committees and the project (in an advanced feasibility stage) to set up a special area-marketing organisation confirm this.

\subsection{The Final Reconciliation for the City Plan and Re-opening of Tables (2005)}

2004 was the first intermediate milestone date for the 2002 City Plan ending in 2010. During a public meeting in April 2005, the city administration presented the Plan Outcomes divided by specific targets and actions. This meeting was also the right moment to launch participation on new priorities:

- the Social Urban Plan, a specific project/plan through which the City Council wants to re-launch public and social resources to increase town 'well-being' through wider, more complete implementation of previous, partially achieved targets;

- the Waterfront and Area project, based on the 'Fresco' donated to the town by the architect Renzo Piano (redesigning the entire waterfront) - a 'final' opportunity to combine port development with urban renewal;

- economic development which through the initiatives and experience lived with Genoa, European Capital of Culture now definitively gives new added value to the art and culture heritage, and extends this to tourism and developing the city's industrial heritage.

These priorities are being managed and processed:

- by the City Council for the Social Urban Plan; 
- by the Port Authority (with help from a special coordinating body set up by the Port Authority, the Region, the Province and the City) for the Waterfront and Area project;

- within the Development Committee for Economic Development.

Based on all this, the town administration has planned a new Strategic Conference for the beginning of 2006. This will update the City Plan and associated strategy to 2015 and target city action till the end of this administrative cycle in 2007.

\section{Medium-Long Term Planning, Tools and Governance Styles}

The Genoa experience confirms that strategic, metropolitan area projects are really complex for several reasons (legal, technical, economic) and, above all, because of the interests involved.

When transversal problems affecting the entire area, the population and manufacturing system are being dealt with, innovative governance styles must replace traditional techniques. The latter tend to focus on limited segments from the area, sector, time and economic points of view. Under this rationale:

- area socio-economic development problems are handled in a limited environment, based on the responsibilities of individual bodies and institutions;

- internal management complexity prevails over extensive planning so each specific problem is handled by applying the appropriate organisational solutions;

- interaction between public entities is controlled exclusively by a legal and institutional framework governing a specific matter; agreements between different players involved are based exclusively on the formal tools and procedures as stipulated in regulations;

- relations between public and private places the former in a position of supremacy over the latter. The private sector is considered the receiver of policies and actions decided on by the public sector. The private sector is very rarely involved in planning and implementing area public policies actively, jointly responsible with the public sector.

Medium-long term planning imposes a different kind of governance style that must involve the main economic and social players in identifying problems and solutions in order to ensure adequate, consistent long-term development. This involvement must be dynamic and aimed at the process. It must be field-created by governance, crossing all borders between public institutions and interest groups and cannot count on decisions taken just once for everyone. This does not mean we want to deny the importance of planned organisation and control opportunities such as strategic conferences.

Institutional leadership governance becomes fundamental for process development. Institutions must be able to:

- promote the merit of problems and outcomes requested, in everyone's interest; 
- while ensuring respect for specific prerogatives for institutions involved and their authorities.

The delicate aspects of decision-making processes linked to strategic choices require a specific 'governance style':

- careful and suited to the political, economic/entrepreneurial and legal/administrative aspects;

- able to set up innovation and design collaboration through the varied institutional and social entities with no 'incidents en route' that could block the process.

Embedding actions and positive experiences such as 'Genoa 2004' case shows, are particularly important as they create a new, propulsive attitude amongst people involved in the city development: a base is created for getting over both 'return position' attitudes and any sector environments that tend to be collusory and not typical of projects.

The Genoa experience proves that a suitable governance style is essential for local development, and planning tools are just as essential. The complexity of legal/administrative and technical aspects and the time and economic importance involved require high process organisation and information structuring levels to support both decision-makers and technicians/managers.

Constructing, managing and continually updating the City Plan helps administrators and local authority offices lay the bases for that authoritative behaviour shown to be a determinant for local governance.

\section{Bibliography}

Bisio Luca, Corporate Responsibility and Local Corporate Governance in Europe, Symphonya. Emerging Issues in Management (symphonya.unimib.it), n. 1, 2003. http://dx.doi.org/10.4468/2003.1.09bisio

Brondoni Silvio M., Ouverture de 'Market-Space Management', Symphonya. Emerging Issues in Management (symphonya.unimib.it), n. 1, 2002.

http://dx.doi.org/10.4468/2002.1.01ouverture

Brondoni Silvio M. (ed.), La comunicazione nella Azienda Pubblica. I paradigmi di efficacia e di efficienza, Giappichelli, Turin, 1999.

de Woot Philippe, The Challenges of Economic Globalisation: Business, Competition and Society, Symphonya. Emerging Issues in Management (symphonya.unimib.it), n. 2, 2002. http://dx.doi.org/10.4468/2002.2.03dewoot

Ferrara G., Comunicazione dell'azienda pubblica e soddisfazione dell'utente, S.M. Brondoni (ed). La comunicazione nella Azienda Pubblica. I paradigmi di efficacia e di efficienza, Giappichelli, Turin, 1999.

Gnecchi Flavio, Gli enti locali e le loro aziende: comunicazione e pubblici esterni, S.M. Brondoni (ed). La comunicazione nella Azienda Pubblica. I paradigmi di efficacia e di efficienza, Giappichelli, Turin, 1999.

Mazzoleni M. Il governo economico degli enti locali e la partecipazione dei cittadini, Franco Angeli, Milan, 2004, p. 51.

Mele R., Economia e gestione delle imprese di pubblici servizi tra regolamentazione e mercato, Cedam, Padua, 2003. 


\section{Notes}

${ }^{1}$ See Mazzoleni M. Il governo economico degli enti locali e la partecipazione dei cittadini, Franco Angeli, Milan, 2004, p. 51.

${ }^{2}$ See Bisio L., Corporate Responsibility and Local Corporate Governance in Europe, Symphonya. Emerging Issues in Management (symphonya.unimib.it), n. 1, 2003.

${ }^{3}$ See de Woot P., The Challenges of Economic Globalisation: Business, Competition and Society, Symphonya. Emerging Issues in Management (symphonya.unimib.it), n. 2, 2002.

${ }^{4}$ See Brondoni S.M., Ouverture de 'Market-Space Management', Symphonya. Emerging Issues in Management (symphonya.unimib.it), n. 1, 2002.

${ }^{5}$ See Mazzoleni M. mentioned above, p. 51

${ }^{6}$ See Mazzoleni M. mentioned above, p. 57

${ }^{7}$ See Mazzoleni M. mentioned above, p. 53

${ }^{8}$ This aspect is specifically significant when getting over problems from the possible effects of alternating political coalitions in local government. Strategic planning must be able to put forward general targets that ensure a lasting commitment, even political, to implementing them.

${ }^{9}$ The Port Authority is independent of the City Council that, together with other social and production entities alongside Region and Province, is only one of its governing body members (Port Committee).

${ }^{10}$ Genoa City Council was created not that long ago (1936) when various small towns were grouped together.

${ }^{11}$ The City Plan drafted during the Strategy Conference was based on 5 strategies each then split into targets and actions:

- city of culture and tourism, to rediscover and add value to the enormous town, art and cultural heritage inherited from the Sea Republic; to make it a founding element in new town quality and to develop tourism;

- united, educational town, to respond to demands for a new quality of life, adding value to town associations and education bodies;

- conditions for new development, for sustainable development that overcomes negative environmental effects;

- $\quad$ area resources for a liveable town, widespread renewal through adequate area maintenance and added value;

- $\quad$ port town and infrastructure, to ensure port development overcomes any negative effects on the town.

12 See Ferrara G., Comunicazione dell'azienda pubblica e soddisfazione dell'utente, S.M. Brondoni (ed). La comunicazione nella Azienda Pubblica. I paradigmi di efficacia e di efficienza, Giappichelli, Turin, 1999; Gnecchi F., Gli enti locali e le loro aziende: comunicazione e pubblici esterni, S.M. Brondoni (ed). La comunicazione nella Azienda Pubblica. I paradigmi di efficacia e di efficienza, Giappichelli, Turin, 1999; Mele R., Economia e gestione delle imprese di pubblici servizi tra regolamentazione e mercato, Cedam, Padua, 2003.

13 In different cases, correlations between programming tools are better when created independently by the Local Authority. As far as Programming Agreements, Suburban Contracts, Urban Renewal Programs and Sustainable Area Development or important community projects such as Urban are concerned, coordination between the different programming levels is more immediate between City Plan (Strategic Plan) and Plan of Targets assigned to Managers (annual budget description) than through traditional economic and financial planning tools such as the multi-year and yearly budgets. These suffer from visions lying within the city administration organisation.

In any case, the City Plan is the best tool available to satisfy the coordination and process nature of strategic planning. As said above, it states the roles for all players involved for each target action, plus all resources involved whether provided by the town itself or by other local, state and community bodies or by private players.

${ }^{14}$ Programming subjects are handled carefully both during Agenda preparation (drafted by the Mayor) so that they are dealt with effectively in the time available (generally there are no more than 
1-2 per session) and for information needed (generally with a technical presentation by managers often by the director of the City Plan Organisation Unit).

Subjects are carefully monitored: the Head of the Mayor's cabinet has a special objective: relating to General Management, indicating what updating is required by programming tools.

15 Preparing and managing actions and events for this converged all public bodies and central government itself towards defining and implementing individual programs.

The activity program was drawn up by a Committee including top management from the City Council, Province, Region and Culture Ministry. The above bodies specifically set up a company to organise it.

There was a lot of participation in drawing up the program. Proposals were collected from hundreds of parties involved in cultural and social town activities - from small associations to cultural institutions. 